\title{
Geochemical characters of muscovite from the Pan African Mandi Granite, and its emplacement and evolution
}

\author{
NC Pant* and A Kundu
}

Geological Survey of India, NH-5P, N.I.T., Faridabad-121001, INDIA

* For correspondence, email: pantnc@rediffmail.com

The Mandigranite, awell known Palaeozoic granite of the Himachal Himalaya, is emplaced in the medium grade metamorphic rocks of Vaikrita Group. The development of andalusite in the contact aureole of Mandi granite indicates its emplacement depth to less than $12-14 \mathrm{~km}$. Several petrological variants such as porphyritic granite, fine-grained porphyritic granite and trondjhemitic granite within the Mandi pluton have been recognized (Chatterjee 1976, Gupta 1994, Kundu et al. in press). Muscovite is a ubiquitous mineral in all of these variants. Muscovite is an indicator of crystallization history of granite. Thus, it is important to assess the magmatic or metamorphic nature of this mica.

Muscovite is present in variable amounts in the Mandi granite. They vary from being nearly absent to greater than 10 mode \%. Textural features such as subhedral nature, sharp grain boundaries and high modal proportion indicate at least some of these to be a magmatic mineral. Igneous nature of muscovite is also indicated by their chemistry (Higher $\mathrm{Ti}$ in porphyritic and trondjhmetic granite in $\mathrm{TiO}_{2}-\mathrm{Fe}_{2} \mathrm{O}_{3}-\mathrm{MgO}$ plot; Monier et al., 1984; higher $\mathrm{Al}$ and $\mathrm{Na}$ and lower $\mathrm{Mg}$ and Si; Miller et al. 1981). The metamorphic/later muscovites are clearly distinguishable on chemical criteria. The magmatic muscovites are associated with apatite, monazite and zircon. In deformed granites such coarse grains are commonly present as mica fish. Many of such coarse muscovite grains have a brighter rim which commonly has a trail of small grains of sphene. The rim portion of such grains have higher phengite component ( $\mathrm{FeO}-4$ to $4.5 \mathrm{wt} \%, \mathrm{MgO}=0.55$ to $1.5 \mathrm{wt} \%)$ and lower paragonite component $(\mathrm{Na} / \mathrm{Na}+\mathrm{K}=0.03$ to 0.04 ) than the core of the grains. Another textural variety of muscovite is present as fine grained flakes in foliated granites as part of the matrix. It defines the foliation plane in these granites. Such grains have compositions similar to the rim portions of large grains.

A cursory examination of the mineral chemistry of muscovite presented above indicate that significant percentage of the muscovites are of primary origin based on their $\mathrm{Na} / \mathrm{Na}+\mathrm{K}$ ratio an observation opposed to that of Nag et al. (2005). The upper stability of muscovite has been considered as $4 \mathrm{kbar}$ and in view of the emplacement of Mandi granite at equivalent depth, as inferred from the development of andalusite in the contact zone, the emplacement conditions are well constrained. Micas of the Mandi granite and associated rocks have been used to decipher the emplacement conditions and evolutionary history of Mandi granite. 